'On different levels ourselves went forward': pageantry, class politics and narrative form in Virginia Woolf's late writing.

\title{
Ben Harker
}

In August 1936 the Rodmell village branch of the Labour Party held its monthly meeting in the usual venue, Monk’s House, the home of Leonard and Virginia Woolf. Those present included the Woolfs, the village postman Mr Fears and his wife, farmworker Mr Hubbard, the Woolfs’ domestic servant Louie Everest (branch secretary) and her husband Bert, a labourer at the nearby cement works. ${ }^{1}$ A number of the assembled activists were also the Woolfs' employees and tenants, and entrenched class dynamics rubbed against more egalitarian objectives: as recently as the 1929 General Election Virginia Woolf had been jolted by the realisation that she and her servants wanted the same side to win, reflecting in her diary that 'to be ruled by Nelly [Boxall] and Lottie [Hope] would be a disaster. ${ }^{2}$

As Raymond Williams points out it in his essay 'The Bloomsbury Fraction', the Woolfs' circle had never been the politically disengaged aesthetes often caricatured by the left. Indeed, one formative structure of feeling shared by this 'dissident fraction’ of the highly educated professional, non-industrialist English middle class had always been a 'social conscience' which took the form of 'a quite un-self-conscious and quite pure patronage' to lower classes and a correspondingly critical attitude to 'the cruelty and stupidity of the system' created and sustained by the hegemonic middle class. ${ }^{3}$ Williams distinguishes this from another way of relating to the lower class, for Williams never taken seriously by Bloomsbury at its height: identification with the “"social consciousness” of a self-organizing and subordinate class' (Williams’ emphasis). ${ }^{4}$ 
The topic for discussion at Monk’s House in August 1936 was the popular front, an ongoing and often divisive movement pushing for communists, socialists, liberals and even progressive conservatives to unite around ideas of nation, tradition and democracy in a political and cultural coalition to resist the rising fascist threat along the lines demonstrated by newly elected governments in Spain and France. ${ }^{5}$ Leonard Woolf was an advocate of the popular front, and the meeting debated and at some level enacted a new political mood which indeed brought Bloomsbury veterans like the Woolfs into the type of close contact with the 'social consciousness of a subordinate class' unimaginable a decade before. ${ }^{6}$ If the economic convulsions of the depression years had brought the working class knocking on the Woolfs' door, as earlier that year when the couple came to the aid of a destitute seamstress, the famously radicalising conjuncture of the mid 1930s created a space in which the Woolfs would share a platform with communist singer and actor Paul Robeson, in which Leonard Woolf would write Barbarians at the Gate (1939) for communist front organisation the Left Book Club, and in which Virginia Woolf would support the communist dominated organisation the Artists International Association (AIA) and publish an article in the Communist Party’s Daily Worker newspaper. ${ }^{7}$ Her piece for the Daily Worker was marked by a political reticence conspicuous in a newspaper launched seven years earlier as 'a strong antidote to the poison gas of the bourgeoisie’; for Virginia Woolf such texts and contexts were not sites of thoroughgoing political conversion, nor of the renunciation of class privilege and cultural preference, but of ambivalence and conflict in which she by turns asserted the desirable separateness of artistic and political practice and regretted the 'besieging voices’ now calling for their convergence. ${ }^{8}$ 
This article is about late Woolf's negotiation of those besieging voices, in particular the inner voices murmuring dissatisfaction with the subjectivism widely associated with high modernist aesthetic assumptions, priorities and textual strategies. In particular I focus on Woolf's final novel Between the Acts (1941), and the late essays, letters, and diary entries that surround it. The novel has frequently been discussed in terms of the Second World War and, more recently, in relation to English late modernism's contraction to insular nationalism within the context of declining Empire and the fading away of the metropolitan perspectives generated by colonialism. ${ }^{9}$ My analysis pushes an overlapping but critically overlooked context into view: the particular political and class alignments of the popular front period—in which the Communist Party re-branded itself as 'the very essence and spirit of the English tradition' — and those discourses around national history and traditions that characterised the period of the text's composition. ${ }^{10}$ I present the novel as the conflicted location of a search for a more inclusive narrative form, and in particular as a text which engages leftist discourses and cultural forms whilst symbolically mediating and managing tension between historically produced, class-bound ways of seeing and not seeing individuals — the structures of feeling shared by the Bloomsbury fraction—and the competing collectivist pressures of the historical moment.

Though Between the Acts (1941) is most often discussed in the context of the war years, Woolf first alluded to the book on 12 April 1938. ${ }^{11}$ 'Last night I began making up again’, she wrote in her diary, ‘Summers night: a complete whole: that's my idea'. ${ }^{12}$ She picked up the thread a fortnight later on a day when her mind was also caught up with the recently deceased patron and hostess Lady Ottoline Morrell, a 
figure synonymous with an earlier Bloomsbury period of scenic sanctuaries and aesthetic innovation which Woolf elsewhere contrasts favourably, if half-ironically, to the present time when writers and artists were expected to 'do their talking in public': ${ }^{13}$

[...] here I am sketching out a new book; only dont please impose that huge burden on me again, I implore. Let it be random \& tentative, something I can blow of a morning [...] But to amuse myself, let me note: why not Poyntzet Hall: a centre: all lit. discussed in connection with real little incongruous living humour; \& anything that comes into my head; but "I" rejected: "We" substituted: to whom at the end there shall be an invocation? "We”...composed of many different things...we all life, all art, all waifs \& strays—a rambling capricious but somehow unified whole - the present state of my mind? And English country: \& a scenic old house — \& a terrace where nursemaids walk? \& people passing — \& perpetual variety \& change from intensity to prose. \& facts— \& notes; \& — but eno'. ${ }^{14}$

The new text was conceived in a spirit of truancy ('to amuse myself') from the political super ego that had overshadowed Three Guineas, Woolf's anti-fascist polemic created under 'a lash of compulsion' after a protracted and fraught attempt to write the more politically engaged novel eventually published as The Years (1937): 'I've done my bit for that cause, \& cant be bullied', she wrote in her diary the day the final proofs to Three Guineas were submitted. ${ }^{15}$ Even so, the emphasis on cultivated contingency here — 'random \& tentative', 'rambling, capricious'—is balanced by an 
ongoing obligation to ‘a complete whole’: 'but "I” rejected: "We” substituted: to whom at the end there shall be an invocation?' The individual is to be dutifully supplanted by the collective, even if the scare quotes and question mark highlight an unresolved tension between those terms.

That tension constituted the force-field in which Woolf's final novel was written. The original working title of 'Poyntzet Hall' — which promises a country house novel focussed on its inhabitants—soon yields to 'The Pageant', with its emphasis on an event that draws together the wider community. ${ }^{16}$ The text's own embryonic development also reflects the pull. Woolf briefly considered abandoning writing a novel to be read in private in favour of a play for public performance, a shifting focus between privileged privacy and inclusive performance also played out in one of the text's running jokes: ${ }^{17}$ Pointz Hall was built in the wrong place in its grounds; the Pageant, by contrast, 'substitutes' the house, being performed where the house should have been built, on a natural stage surrounded by pillar-like trees. ${ }^{18}$ With its narrative panning from domestic interior to cultural event then back again, the text at once traces and enacts the search for a cultural form where the 'I' opened out into the 'We' which had been the central preoccupation of Woolf's career in the wake of The Waves (1931). Written over a three-year period, the new text was generated by and responded to a kaleidoscopic historical and political context. It was conceived amidst popular front debates about the need for art to follow politics in the name of foregrounding aspects of a national cultural tradition inherently and robustly resistant to fascism. It shades into a text refracting the often awkward inter-class solidarities of the early war period characterised by Woolf as a time of uninvited villagers calling at Monk’s House and poking her lawn with sticks while asking how to grow potatoes. ${ }^{19}$ Completed at a moment when the barbarians were at the gate and 
Nazi invasion looked likely, the text is compelled to preserve and reactivate the cultural past and to prefigure faintly within its frame the outlines of a post-war future in which the 'orts, scraps and fragments' $(B, 111)$ of a blitzed civilization might be rebuilt into a society that creates from the solidarities of the war years a different social order, 'all liberated; made whole' $(B, 109)$.

\section{II}

The novel’s primary medium for this ‘invocation’ of collectivity is a pageant staged on a June day in 1939. Woolf makes a point of registering that this is the seventh annual pageant to be held at Pointz Hall $(B, 16)$; with the first pageant therefore held in 1933, the event is not the annual flowering of organic folkways but, like the pageant form itself, an always invented tradition and in this case part of a wider 1930s pageantry revival. The decade's revival of a style of pageantry previously dominant in the pre 1914 period was, in part, another instance of a familiar late 1930s imaginary retreat from a vertiginous present to an era characterised by Woolf as one of 'long summer holidays'. ${ }^{20}$ But there was more than reassuring nostalgia at work here: in various manifestations of active historicism the pageant form enjoyed a significant revival across the 1930s political spectrum. If cultural forms are strategies for dealing with situations, the 1930s pageant, resurfacing at a moment that was, in the words of John Lehmann, 'haunted by the feeling that time was running out' was the site of ideologically contested historical retrieval, consolidation, and projection which sought to explain the present and uncover the future in the patterns of the past. ${ }^{21}$ The romantically anti-capitalist, pro-feudal pageants produced by Woolf’s Bloomsbury friend E. M. Forster — one of his texts was published by the Woolfs' Hogarth Press in 1940 - found both the roots and answers to the current crisis in the past. ${ }^{22}$ Forster's 
pageantry presented the period between the Magna Carter and the Eighteenth Century as pastoral continuum uninterrupted by history, and argued that England lost its way with the enclosure of common land, the break up of large estates and the commodification of agriculture. ${ }^{23}$ T. S. Eliot's The Rock (1934) celebrated the unifying force of national religion and, like the pageant in Between the Acts, was staged to raise funds for the Anglican Church. ${ }^{24}$ The pageants marched, performed and published by the Communist Party during the popular front period constructed a teleological narrative of progress stretching from the democratic rights encoded in the Magna Carter through to Harry Pollitt, the General Secretary of the organisation now positioning itself as 'the legitimate heir of generations of great English fighters for freedom and progress' and uniquely capable of releasing the radical and democratic traditions of the national past into a future 'Free and Merry England. 25

Woolf wrote, or at least began, two pageants in this period, one staged by Miss La Trobe in Between the Acts (discussed below), the other an abandoned 1940-1 parallel book provisionally entitled 'Reading at Random' then 'Turning the Page' and published posthumously as the fragmentary essays 'Anon' and 'The Reader.' ${ }^{26}$ This text, with which Miss La Trobe’s pageant can productively be compared, planned to trace the genealogy and 'continuity of tradition': [t]he idea of the book', Woolf wrote in her notes 'is to find the end of a ball of string \& wind out' $(A R, 373)$. If Woolf in the late 1930s was caught between valuing the autonomy of culture and reluctantly recognising that such autonomy was being compromised by historical crisis, Woolf in the early 1940s was further oppressed by the sense that war had violated the civilised context in which the necessary symbiotic cultural exchange between writers and readers took place. The reader's historical importance, as she noted in the essay 'The Reader', 'can be gauged by the fact that when his attention is distracted, in times of 
public crisis, the writer exclaims: I can write no more' $(A R, 428)$. The present was such a moment, as she noted in July 1940: 'There’s no standard to write for: no public to echo back. ${ }^{27}$ The image of finding 'the end of a ball of string' at once spoke of the desire to overcome aesthetic isolation through establishing connection with a collective, national cultural tradition—in 1931 Edmund Wilson had complained that recent aestheticism was 'completely self-contained and does not lead to anything beyond itself' - and the desire somehow to follow the thread of cultural continuity out of the maze of the historical the moment. ${ }^{28}$

Whereas the fluent discursive pageantry created by the communist left, such as Edgell Rickwood’s ‘Culture, Progress, and English Tradition’ (1937) and Christopher Caudwell's excavation of the sources of poetry in Illusion and Reality (1937), was emboldened by confidence that political action on the side of the working class could rapidly and productively reconnect intellectuals and artists to the rhythms of popular life, Woolf's tentative text was a search for meaning rather than the declaration of a well-rehearsed position ${ }^{29}$ She saw her task as a re-writing of English literary history which sought to strike a new balance between context - 'the affect; the growth; the surrounding' — and the trans-personal, trans-historical afflatus behind creativity, 'the inner, current' which was 'all left out in text books' $(A R, 374)$. She planned to write chronologically, but to avoid the crude segmentation ('No "periods"”) that risked privileging contextual change over the ongoing creative drive $(A R, 373)$.

She opened the first essay, 'Anon', with the 'desire to sing', which she imagined initially being stimulated in a primitive huntsman who, hearing birdsong, lays down his axe to listen $(A R, 382)$. From this inaugural scene, Woolf followed Forster's pageantry in presenting a positive account of 'the common voice' of creativity circulating freely around the social structures of the feudal period, a cultural 
exchange which left 'tracks across the fields joining manor house to hovel, and hovel to church' $(A R, 382,383)$. She then traced the folk energy of 'Anon'—who was organically integrated into his audience, functioning as a conduit for shared feelings and perceptions — through the Middle Ages, arguing that the invention of printing 'foretold the end of that anonymous world', bringing the 'past into existence' by codifying it into 'the settled' record $(A R, 385)$. Here some hesitation about the ongoing presence of ‘Anon’ first enters her discourse, but she is clear that printing technology enabled the emergence of a proto-modern literary intelligentsia embodied in figures such as William Harrison, a contributor to Raphael Holinshed's Chronicles (1577). ${ }^{30}$ In contrast to Anon’s porous plurality, Harrison represents a sharply defined 'individual' who 'sees himself and shows himself to us' in his writings ( $A R$, 385). Woolf argues that in this period of patronage and emerging self-conscious literariness, the poet becomes less a common muse than 'a man practising an art, asking for recognition’ (AR, 391). Anon’s song only reminds figures like Harrison of 'his lack of intellectual ancestry', which is now sought out in classical and continental sources $(A R, 385-6)$. With his song denied, Woolf argues, Anon is forced underground, only to re-surface in the Elizabethan playhouse, a space which bucks the trend of social stratification, encompassing 'gentry and commons' and where Anon's energies can infuse the work of playwrights, enabling 'great strides [...] beyond the reach of the solitary writer with his mind fixed upon the reader' $(A R, 392,395)$. The Elizabethan stage's highly productive tension between folk energy and authorial vision is, however, short-lived, as the balance soon tips in favour of the latter. 'Anon' yields to 'more detached, more mature drama'; writers increasingly reflect audience concerns; the 'more differentiated' 'individual' becomes a mainstay of the drama ( $A R$, 398). Though Woolf's first essay closes with the words 'Anon is dead' (she wrote 
'Anon is dead forever' in the more emphatic draft) the obituarising is checked by the caveat that Anon's 'nameless vitality' is 'not yet dead in ourselves', and can be accessed through reading the plays 'to which no one has troubled to set a name' ( $A R$, 424, 398). In another context Woolf also detected the ongoing vitality of oral culture in the spontaneous creativity of working-class speech. ${ }^{31}$

In a well-documented block, however, Woolf was unable to narrate the link to the next section, and abandoned the project after six attempts ( $A R, 425)$. A pageant first conceived as threading a necklace through life and literature came unravelled in the transition from 'Anon' to the sequel essay, 'The Reader'. Writing in a moment suspended between an irrecoverable pre-war past and an uncertain future, she was also unable to connect the democratic energies of oral culture to more modern sensibilities, commenting in a letter on 1 March 1941, 'I am stuck in Elizabethan plays. I cant move back or forwards. I've read too much, but not enough. That's why I cant break into politics. 32

Though it appears on a casual reading a non-sequitur, her inability to 'break into politics' shows Woolf alluding to a set of contextual questions that loom on the edge of her discourse without being assimilated into her argument. Feudalism is presented positively without being explicitly endorsed as a social model—as by Forster in his pageants_-and Woolf's text breaks off in a period variously described by her contemporaries as the point where the string of an earlier tradition snapped in a historical rupture, the frayed end of which was the modernist fragmentation and introspection for which she was often chastised. For F.R. Leavis the moment famously marked the beginning of the long disintegration of a common culture which culminated in the hardened cultural stratification of high and lowbrow which Woolf's writings were used to illustrate. ${ }^{33}$ W. H. Auden’s chronological, pageant-style 
introduction to The Oxford Book of Light Verse (1938) presented the Elizabethan period as a moment whose cultural renaissance was enabled by the complex seeing of a society on the cusp of profound economic, social and political change. For Auden, however, as for Leavis, this paved the way to a present 'amorphous society with no communal ties' in which artists increasingly turned inwards to 'their own emotions and the contemplation of imaginary worlds'. The artist could only be re-integrated, Auden argued during a moment of popular front optimism, in a classless democracy in which privileges previously enjoyed by 'the wealthier few' could be universally shared. ${ }^{34}$ And Christopher Caudwell's materialist analysis broke into politics, or political economy, even more emphatically, polemically presenting the Elizabethan period as the origin of the present, a key moment in the formation of middle class consciousness and culture. Here, argued Caudwell, the once revolutionary dynamism of the middle class broke through the fetters of feudal modes of production and channelled society's productive forces into the market structures of capitalism, a process shaped by and shaping the ideology of individualism which presented the market and private property as the true contexts in which humankind could express its natural, individualistic core. For Caudwell, this foundational ‘bourgeois illusion’ lay in naturalising the historically particular ideology of individualism. ('The bourgeois ceases to be a bourgeois', he wrote, 'as soon as he becomes conscious of the determinism of his social relations'). ${ }^{35}$ And for Caudwell, as for Auden, these profound economic, political and social convulsions made themselves felt in cultural forms: the drama of the Elizabethan stage was 'the product of a society passing from collectivity to individuality., 36 '[I]n the sphere of art', he added, 'bourgeois culture [...] produced the increasing individualism which, seen at its best in Shakespeare, was 
a positive value, but pushed to its final limit spelt the complete breakdown of art in surrealism, Dadaism and Steinism., ${ }^{37}$

Caudwell's ideologically-driven project was critically to narrate the rise and fall of modes of production, and to trace their cultural manifestations. Historical rupture — notably the emergence, consolidation and decline of social classes—was at the heart of an analysis forecasting the 'movement forward from bourgeois culture to communism'. ${ }^{38}$ Woolf's challenge on the other hand, to get inside English literature and trace the various incarnations of a trans-historical 'song making instinct' through different economic, political and cultural contexts (abbreviated by Woolf to 'Nin, Crot and Pulley'), was instead invested in presenting a cultural continuum that would loop the individuated ' $\mathrm{I}$ ' of late modernism into the 'we' of national tradition ( $A R$, 373, 360). Her fraught and fragmentary text, which desires but doesn’t successfully establish an unbroken link from Anon through to the individuated subjectivities of modernity, significantly begins by positing the individual consciousness at the primal scene of culture. The popular front left frequently began their pageants by grounding the origins of culture in collective work; locating the origins of speech, dance and song in the rhythms of bodies in labour, they proceeded to present the socialist future glimpsed in the popular front as a moment when culture would return from its alienated capitalist state and come home to labour ('culture and labour' were considered 'mutually dependent aspects of the productive process'). ${ }^{39}$ Woolf instead imagined culture's flow beginning with the primitive huntsman at rest; the song of 'Anon' is generated not through collective labour but by the individual huntsman withdrawing from labour, and she quotes the early English lyric 'By a bank as I lay / Musing myself alone, hey ho!' to make the point ( $A R$, 382). Presenting the embryonic individual consciousness as the source of the song, she conceives Anon as 
a proto-individual, thereby naturalising and universalising a particular way of seeing — the individual's viewpoint—-which later in 'Anon' she presents as historically generated and emerging at the dawn of modernity in the Elizabethan period (the 'individual emerges') ( $A R, 385)$. Woolf's inability or unwillingness to conceptualise Anon's cultural forms as collectively generated-even while she is actively committed to celebrating their collective charge-is in synch with the Bloomsbury group's cast of mind, which intensified rather than broke with their class's emphasis on individualism. 'Awareness of their own formation as individuals within society', writes Raymond Williams, 'of that specific social formation which made them explicitly a group and implicitly a fraction of a class, was not only beyond their reach; it was directly ruled out, since the free and civilised individual was already their founding datum. ${ }^{40}$

And if Bloomsbury emphasis on the civilised individual reinforced rather than contested middle-class culture's naturalisation of its historically generated ways of seeing, Woolf's analysis, which at once strives and struggles to integrate text and world, artistic and contextual frames of reference, also operates from within an overarching conceptual paradigm which assumes the split of subject and object, consciousness and reality, and which is inclined to present culture as an object outside the world rather than a practice which plays a part in shaping that world. These essays are not only struggles for social meaning, but as Woolf acknowledged from the outset, for critical method. At some moments, as when she individualises Anon, culture is de-materialised or abstracted from social relations, and the past is conceived in the image of the present; at others Woolf works with an inflexible materialism, notably when she suggests that the printing press, rather than having its uses and meanings shaped by a complex ensemble of social relations, plays a decisive role in 
determining those relations ('It was the printing press that finally was to kill Anon') $(A R, 384)$. 'Keep a running commentary on the External' she reminds herself in her notes, the capitalisation indicating her ongoing conceptual struggle to conceive culture and society as materially inhabited by one another $(A R, 360)$.

Woolf's block between 'Anon' and 'The Reader' implicitly recognised the past as broken, and that something decisive or formative had happened to English social and cultural life in the sixteenth century. But breaking into politics and connecting new ways of seeing to shifts in social formations at once conflicted with constitutive intellectual patterns and pulled against the original assumption about transhistorical afflatus ('the song making instinct', 'certain emotions almost in being') ( $A R, 376,374)$; registering sixteenth-century cultural rupture, in other words, conflicted with the very notion of continuum which had first generated the project (the need to integrate the individuated I into the we of national cultural tradition). And conceptualising the sixteenth century as a moment of rupture or reconfigured class relations not only exiled her from the tradition of 'Anon' to which 'Anon' and ‘The Reader’ sought to connect her, but also re-absorbed Bloomsbury’s radical energies and individualistic sensibilities back into a specifically middle-class cultural story against which Bloomsbury had defined much of its project. ${ }^{41}$ While for popular front intellectuals the sixteenth century was the origin of the present formation of capitalist modernity whose rupture of history could be healed in a collective future drawing previous moments of apparently disconnected struggle against oppression into a redemptive narrative of progress, Woolf harboured few such political illusions during the popular front period, and none in the early 1940s. The best she could hope for in the future was that the present-eagerly conceived at this moment as an extension of the past—should continue. The fragility of that hope in cultural 
continuity is registered when 'Anon's' fragmentary, three-page sequel essay 'The Reader' breaks off at the end of the sixteenth century with the words 'We are in a world where nothing is concluded' (AR, 429).

III

Woolf finished Between the Acts while struggling with 'Anon' and 'The Reader'. Working on the discursive pageant made her to long for 'a new critical methodsomething swifter \& lighter \& more colloquial \& yet intense’, an apt description of the more open critical mode already created in the complex interplay between the fictional pageant and the surrounding text in Between the Acts. ${ }^{42}$ The novel's pageant is best read as a collaboration between Woolf and her fictional alter-ego, the producer Miss La Trobe. Spanning half the novel, La Trobe’s unorthodox performance follows the broad contours of 'Anon’ and 'The Reader', covering national history from the dawn of mythic time to the present, with the pageant providing the focal point around which the novel's events turn. But if 'Anon and 'The Reader' strove for the narrative cohesion of threading a necklace through English literature, this theatrical pageant is disjunctive in its mode and finds dramatic forms to embody key ideas around which those essays, with their vexed commitment to cultural continuity, prove hesitant: ${ }^{43}$ that the emergence of print culture, reading and what Woolf calls 'the theatre of the brain' brought the past into existence by dissolving it (AR, 398); and that the possibility of writing or staging a pageant is intimately connected to the loss of the putative communality, anonymity, orality and immediacy that on one level it strives to recreate. 
Where those essays sought to narrate continuity between an unlettered oral culture and later literature, this pageant works through paratactic juxtapositions of fragments of oral culture and more sustained literary pastiche. Running through the pageant, for example, is the nursery rhyme 'Sing a Song of Sixpence', which is first called to the mind of the audience via a gramophone tune $(B, 70)$, then appears in the pageant as a contrapuntal prelude to a literary sketch $(B, 74)$, and later reverberates through the private thoughts of Isa Oliver $(B, 106)$. Through this device of playing the rhyme off characters' interiority and the pageant's periodised literary pastiche, Woolf frames rather than traces cultural continuity and questions rather than resolves the sources of the rhyme's ongoing resonance. Whereas Woolf's nephew Julian Bell, who was politicised during the popular front, drew this anonymous oral fragment from the past into the present, up-dating the text of the nursery rhyme in his poem 'Nonsense' (1938) to straighten out and make current and explicit for the modern reader the rhyme’s jumbled political undertones about power, privilege and class, Woolf allows the darker tones to ring through, leaving in tact what Fredric Jameson calls the 'essential mystery of the cultural past'. ${ }^{44}$

Relentlessly 'textual' in its representation of the past, the pageant also dispels the notion-implicit amongst pageants with more obvious ideological agendas-that the past is somehow directly available for representation independently of the cultural forms through which it is known. In simultaneously creating what one critic calls 'representation of history and a history of representation', Woolf and La Trobe’s collaboration showcases its own historical situatedness, dramatising that the historical past is being revued from a given moment and that active selections are being made. ${ }^{45}$ What is submerged in 'Anon' and 'The Reader' is clear here: that a 'tradition' does 
not exist outside of attempts to construct it, and that culture is not an object 'reflecting' the external 'reality’ of its moment, but a mode of the real's formation.

Critics of Woolf who present this pageant as straightforward cultural recapitulation gathering together a national tradition at a moment of great historical pressure, therefore overlook its philosophically savvy rationale and accumulative critical force. ${ }^{46}$ Woolf's text subverts the patriotic or Empire Day pageant which some of the audience expect $(B, 94, B, 106)$ : far from presenting the national narrative of a country destined for greatness, the performed pageant opens with the embodiment of England forgetting her lines $(B, 48)$. And if 'Anon' and 'The Reader' struggled to situate cultural shifts in relation to determining historical ruptures and emergent forms of consciousness-preferring to see culture as powered by eternal, internal dynamics and instincts — the paratactic aesthetics of La Trobe’s pageant repeatedly make connections between economic material history and cultural forms, glimpsing culture’s political unconscious sometimes hidden from view in ‘Anon’ and 'The Reader', and often bracketed off as 'External'. The cultural flowering of the Elizabethan age upon which 'Anon’ foundered is here explicitly grounded in the maritime and imperial expansion of 'Hawkins, Frobisher, Drake' $(B, 52)$; the Age of Reason is set off against the disquieting nonsense and class hierarchies of 'Sing a Song of Sixpence' and shown to be undergirded by 'savage' labour in 'distant mines' $(B, 75)$; the carefully modulated spoof Restoration Comedy 'Where There’s a Will There's a Way' is precisely attuned to the genre's historical anxieties that, in a late seventeenth century moment of recoinage, the circulation of seemingly valueless paper money and national debate about credit, currency and financial institutions, relationships between essence and appearance, real and apparent worth, are volatile. ${ }^{47}$ Finally, the dramatic modes used to parody the Victorian culture so central to the 
Bloomsbury circle's oppositional formation are realist in proportion to the efficacy with which polite social discourse represses questions of imperial and patriarchal power (B, 99-100). Here the pageant in Between the Acts functions as a type of dreamwork which brings into partial view culture's repressed material origins, forever implying that the novel's present— Pointz Hall, the village, Bart Oliver the retired colonial administrator, his son, Giles Oliver the stockbroker-is shaped by historical processes darker and more complex than the usual conventions of pageantry or words like ‘tradition’ or ‘continuity’ capture.

At the same time as unsettling the apparent solidity of the novel's framing topos, however, both the pageant and the surrounding text are marked by conspicuous silences, and have more to say about imperialism and labour in distant mines than about capital and class at home. Back in July 1937 Woolf had taken a break from writing Three Guineas to visit Clissold Park, Stoke Newington, and her diary contrasts her family’s past in the large house where ‘Grandpapa studied The Times while [his wife] cut roses' with the present which 'smelt of Clissold Park mothers; \& cakes \& tea; the smell—unpleasant to the nose—of democracy.' ${ }^{48}$ Here Woolf's thoughts run from a spacious, preferable past to the odour of a present shaped by inexorable demographic and political forces; in contrast, the imagined society of Between the Acts performs a partially compensatory function, at once registering and holding such forces at bay.

The urban gives way to the rural in the novel. In contrast to 1930s England where, as the Woolfs, E.M. Forster, and Orwell’s George Bowling were all too aware, cherished pastoral locations were never safe from the democratizing spatial 
disfigurement of unsightly bungalows and sprawling suburbanization, the reassuring views in the novel's floating, locationless village have changed little in over one hundred years $(B, 34) .{ }^{49}$ The demographic changes that had erased the old Clissold Park are only glimpsed from the corner of the eye: the novel opens with an oblique discussion about the county council's plan to pipe water to the village (presumably to service a growing population); the text little more than registers the presence of the motor car, the cheap paperback $(B, 12-13)$ and 'the movies' $(B, 117)$; the roll call of the pageant's audience includes industrial workers brought into the region by the nearby car factory and aerodrome $(B, 47)$, but neither the voices of these shadowy characters nor their ordinary cultural habits find a space within Woolf's otherwise polyphonic text. Rather than dramatising the emergence of a class whose self-making was endlessly acted out in 1930s leftist pageantry, as in Jack Lindsay’s massdeclamation poem ‘Not English? A Reminder for May Day’ which dramatised how industrialised class consciousness sharpened to overcome the false consciousness of hegemonic nationalism, the working class here are object rather than subject. ${ }^{50}$ Woolf's text is conspicuously silent around processes of industrialisation, casting labour in pastoral poses_-'digging, delving and ploughing'—as an unobtrusive backdrop to historical change, neither affecting nor affected by events $(B, 74,76,98)$. Unlike the mothers of Clissold Park or the politicised villagers who attended Rodmell Labour Party branch meetings, the village's working people are reassuringly rooted in time and place. Part of the landscape, their continuity with earlier incarnations is such that their names appear in the Domesday book $(B, 21)$ and they play themselves in La Trobes' pageant. That their words are repeatedly lost on the wind is perhaps a wry joke at Woolf's own expense $(B, 76)$ : she was a keen reader of her inconsistencies and her fiction had seldom been able to keep working-class characters in focus. She made 
no secret of being 'much shyer of the labourer than of the gentry' and ambivalence to the shifting composition of social class made itself felt across her late 1930s and early 1940s writing in many forms, from her preference for archaic class designations ('simples' and 'common' rather than 'working-class'), ${ }^{51}$ to using her gender and lack of educational opportunity to slip across the class line and join the 'immense class' of ‘commoners and outsiders' excluded by a patriarchal elite (rather than by structural inequalities), ${ }^{52}$ to the related habit of describing the processes of her own writing'threshed and threshed till perhaps a little more grain can be collected'-in terms that positioned her inside a non-industrial working class. ${ }^{53}$

\section{$\mathrm{V}$}

'Skip the present day', Woolf wrote in her working notes for 'Reading at Random', 'A Chapter on the future' (AR, 375). The abandoned text proposed to gloss over the late 1930s 'present day' in which Woolf had struggled to reconcile present, past and 'besieging voices' calling the artist from more autonomous practices; the montage structure of the final stages of the pageant in Between the Acts, by contrast, textualises these tensions, forming a highly compressed meditation on narrative form which mobilises not only representational strategies associated with modernism—as critics have often recognised—but also those favoured by the besieging voices of the cultural left. The ten minutes of regressive nursery rhymes and 'nothing' freezes the pageant as if to communicate the block brought on by the present ('the times too big? —or too close to us—-for great poetry', as Woolf put it in her notes for 'Reading at Random') (AR, 374). This is followed by a tableau of a man building a wall, a scene which draws upon the representational conventions of popular front leftist spectacle and 
which is eagerly interpreted by the audience as allegorizing the need to rebuild civilization (draft versions of the novel were more explicit here: 'Europe rebuilt [...] All races united—-that was plain'). ${ }^{54}$ But La Trobe and Woolf soon undercut the instrumentality of this too easily decoded scene with one of cast members carrying mirrors, reflecting the audience back to themselves in a form of live Cubism performed to the accompaniment of aggressively discordant music rumoured to be 'jazz’ $(B, 109)$. As though generated from the heart of Woolf’s own textual ambivalence, this famous scene produces multiple perspectives upon which no organising pattern of meaning settles. It foregrounds a crisis in the possibilities of textual reflection of the real through the last ditch strategy of resorting to literal reflection, although the butt of La Trobe and Woolf's humour might just as easily be the surface realism famously dismissed in ‘Modern Fiction’ (1919) as exercising 'immense skill and immense industry in making the trivial and transitory appear the true and the enduring' (the joke is that mirrors give the same results). ${ }^{55}$ At the same time, the mirrors also violate the episodic conventions of reassuring pageantry, slyly alluding to modernist Bloomsbury's capacity to antagonise an older generation who complained of those who 'can’t make, but only break; shiver into splinters the old vision' $(B, 109)$. But in the context of the pageant and its accelerating montage, this modernist atomisation of 'the old vision' — if that is what it is - becomes just one set of representational conventions amongst others.

If the mirrors invoke and partially disavow both surface realism and avantgardism, their involvement of the audience also draws upon and contests leftist agitprop conventions which came sufficiently close to the centre-stage of mid 1930s cultural life to be appropriated by E.M. Forster's pageantry. ${ }^{56}$ In this dramatic mode, which found its central expression in Clifford Odets' Waiting for Lefty (1935) and 
was developed in British popular front productions such as Unity Theatre’s multimedia living newspaper Busmen (1938), the solution to the problem presented by the play is found in synthesis of the play (which has identified and articulated the issues) and the now informed audience acting in concerted political solidarity. Here the call for action breaks the play’s illusion, dissolving the separation between actors and spectators by insisting that we are all historical actors, even though history is not made in circumstances of our own choosing. ${ }^{57}$ Woolf's text invokes and problematises such closure by simultaneously drawing in and shutting out the audience. They are identified as 'The present time. Ourselves', though the fact that they appear as images reified in mirrors raises the possibility that they are destined to be caught in the history of 1939, rather than to participate in that history as active agents $(B, 106)$. If leftist agitprop instructs the audience what is to be done, La Trobe and Woolf's version of the genre raises the question of whether anything can be done in the current context. This question is then underscored by the unspooling of the pageant's structure when characters reappear to speak lines from earlier section in a babel-like cacophony. Either knowingly or intuitively, this device makes a mockery of the 'mass declamations' of united voices favoured by the popular front cultural left, a form seen as a crucible where poetry could be re-connected to working people and from which a new culture could be forged. ${ }^{58}$ By deconstructing the pageant's linear procedures, Woolf and La Trobe’s collaboration also questions whether pageantry's style of historical re-enactment, which seems to bring history closer, actually functions as a screen which keeps the past at bay and denies its recurrent patterns and formative presence.

La Trobe, who is rumoured to harbour 'Russian blood' $(B, 37)$, concludes by addressing the audience through a megaphone, another device widely practised 
amongst leftist theatre groups from Berlin’s Rote Sprachror (Red Megaphone) to British troupes affiliated to the Workers’ Theatre Movement. ${ }^{59}$ An analysis based around class location giving rise to collective consciousness and privileged insight into history's movement is, however, rejected: the audience are flatly told that 'The poor are as bad as the rich' $(B, 111)$ and La Trobe's amplified voice asks how the wall of civilization is to be rebuilt by the likes of those caught in the pageant's mirrors. Back in April 1938 Woolf had imagined her as yet unwritten novel in terms of " "I" rejected: "We" substituted: to whom at the end there shall be an invocation?" 60 Having rejected the class-based analysis presented by the left during the popular front years (according to which the collective and democratic values of the working class were the modern manifestation of England's true spirit), La Trobe finally cues in that long-planned invocation by identifying small moments of individual kindness, sensitivity and fortitude that might tentatively represent the basis of such rebuilding. The final invocation comes as La Trobe's words give way to a piece of music: ...was it Bach, Handel, Beethoven, Mozart or nobody famous, but merely a traditional tune? Anyhow, thank heaven, it was somebody speaking after the anonymous bray of the infernal megaphone.

Like quicksilver sliding, files magnetized, the distracted united. The tune began; the first note meant a second; the second a third. Then down beneath a force was born in opposition; then another. On different levels they diverged. On different levels ourselves went forward; flower gathering some on the surface; others descending to wrestle with the meaning; but all comprehending; all enlisted. The whole population of the mind's immeasurable profundity came 
flocking; [...] Compelled from the ends of the horizon; recalled from the edge of appalling crevices; they crashed; solved; united. And some relaxed their fingers; and others uncrossed their legs.

Was that voice ourselves? Scraps, orts, fragments, are we, also, that? The voice died away. $(B, 112)$

A performance that frequently diverges comically from its producer's intentions here conforms exactly to them, and the narrative tone is conspicuously authorial in this passage. Elsewhere responses to the pageant are sampled from particular characters in a relay of consciousness; here, in more interventionist mode, Woolf's narration pulls back from the scene to describe an experience which hovers between a representation and a projected ideal, with the music figured as both the occasion for social unity and a blueprint for it. Utopian in its energies-Woolf is after all describing the resources from which the past might be extended and a better future created — the passage simultaneously performs its own integration into the projected cultural democratization (shifting from 'they diverged' to 'on different levels ourselves went forward') and casts social and cultural unity in terms of interior aesthetic experience at once soothing ('some relaxed their fingers') and stirring ('others uncrossed their legs').

The basic unit of this collectivity is what Raymond Williams calls the Bloomsbury fraction’s ‘founding datum', or ‘the civilised individual, whose pluralisation, as more and more civilised individuals, was itself the only acceptable social direction' (Williams' italics). ${ }^{61}$ And the occasion for the convergence is the synchronised but private experience of the formal properties of art famously celebrated by the group from Roger Fry to Woolf herself. ${ }^{62}$ This invocation of the we, then, comprises two basic tenets of the Bloomsbury thought being rolled out to 
the population in the description of a democratic cultural experience which both reports upon those pleasures and, in the opacity and nuance of Woolf's prose, is carefully composed to reproduce them. In earlier drafts of the novel the music was unambiguously classical—Bach in version one, 'Bach, Handel, Beethoven, Mozart, or nobody famous' in version two — but the final manuscript edges back from these highbrow associations, and the complex history of social and cultural stratification of which 'highbrow' is a part, and the music becomes, possibly, 'merely a traditional tune’ (a tune by anon). ${ }^{63}$ Perhaps anxious that this individualised and aestheticised version of the future looks too much like the Bloomsbury past writ large, the textual revisions blur the cultural hierarchy implicit in classical music back in the direction of an idea of the folk; in particular towards those folk energies and collective forms that 'Anon and 'The Reader' had struggled to connect to more recent cultural formations and which La Trobe's pageant, by contrast, performatively marks out as locations of mysterious and uncanny alterity—neither present in the culture nor absent from itrather than as links in the unbroken necklace of tradition. Implicit in Woolf's invocation of the 'we', then, is the unresolved tension between highbrow, individualised impulses and a crisis-generated, recursive desire to integrate her writing into a cultural continuum. While the blocked transition from 'Anon' and 'The Reader' could not satisfy this desire, the 'swifter \& lighter \& more colloquial \& yet intense' critical mode of her fictional discourse has already called it into question.

In 1938 the novel had been conceived as an invocation of the we; in May 1940 Woolf had told members of the Brighton Workers' Education Association that 'English 
literature will survive this war and cross the gulf' if 'commoners and outsiders like ourselves' dare 'trespass' on the cultural ground fenced in by a patriarchal elite. ${ }^{64}$ The end of the novel holds out no such vision of a more egalitarian future; the pageant's hesitant invocation of the we dissolves to leave an upper-middle class domestic interior, returning the novel to the starting point indicated by its original working title, 'Pointz Hall.' This spatial withdrawal from public spectacle to private 'big room' $(B, 126)$ correlates with a formal retreat from a narrative in collaborative dialogue with public performance to narrative discourse based around four members of the Oliver family. The contraction of narrative register in turn mediates a retreat from the pageant's active but faltering historical thought, which concludes with an attempt to imagine a different future, to a vision of history as a cyclical process driven from the dark recesses of unreconstructed human essence. Through a series of measured allusions, the novel's coda conflates pre-historic man $(B, 126)$, the Oliver family $(B, 129)$, and Miss La Trobe’s next play $(B, 124,126)$ whose subject matter, like Woolf's, is moving from the collective invocations of historical pageantry towards the violence forever lurking in private civilisation. ${ }^{65}$ If the hesitant collectivism of Woolf's last novel ultimately yields to the overpowering barbarism of contemporary history, its field of vision is likewise circumscribed by an entrenched class feeling that to be ruled by 'Nelly and Lottie' in a post-war social democracy of aerodrome workers, bungalows and mass culture-an emergent society partly repressed by the novel's pastoralism—is also inimical to the free and civilised individual. ${ }^{66}$ Like her late story 'The Legacy', where a love affair between a distinguished politician's wife and a revolutionary workingman ends in double suicide, Between the Acts imagines no future lived across class lines. ${ }^{67}$ 
University of Salford

${ }^{1}$ Alison Light, Mrs Woolf and the Servants: The Hidden Heart of Domestic Service (London: Penguin, 2007), 237.

2 Light, 187.

3 Raymond Williams, ‘The Bloomsbury Fraction’ (1980), reprinted in Problems in Materialism and Culture (London: Verso, 1997), 156, 155.

${ }^{4}$ Williams, 156.

5 'For the past year or two', wrote George Orwell in 1938, 'every Socialist, whether he likes it or not, has been involved in the savage controversy that rages over the policy of the Popular Front.' Review of Fenner Brockway, Workers' Front in New English Weekly, 17 February 1938 reprinted in Sonia Orwell and Ian Angus eds, The Collected Essays, Journalism and Letters of George Orwell, Volume 1, 1920-1940 (1968; London: Penguin, 1970), 340. The Popular Front generated publications such as Left Review, polemical tracts such as G.D.H. Cole, The People's Front (London: Victor Gollancz, 1937) and organisations such as the Left Book Club and Unity Theatre. See Jim Fyrth ed., Britain, Fascism and the Popular Front (London: Lawrence and Wishart 1985) and Lewis Mates, The Spanish Civil War and the British Left: Political Activism and the Popular Front (London and New York: I B Tauris, 2007).

${ }^{6}$ Leonard Woolf's support for the popular front is detailed in John Coombes, 'British Intellectuals and the Popular Front' in Frank Gloversmith ed., Class, Culture and Social Change: A New View of the 1930s (Brighton: Harvester, 1980), 70-101.

${ }^{7}$ An incident related in Woolf's diary on 20 March 1936. Anne Oliver Bell ed., The Diary of Virginia Woolf Volume V, 1936-1941 (New York and London: Harcourt 
Brace \& Company, 1984), 19. The Woolfs appeared alongside Robeson at a public meeting in aid of the Spanish cause held at the Albert Hall on 24 June 1937, an event recounted in Woolf's diary the following day (Diary $V$, 98-9). Leonard Woolf, Barbarians at the Gate (London: Victor Gollancz, 1939). Virginia Woolf, 'Why Art To-Day Follows Politics’, Daily Worker, 14 December 1936. The article was written to coincide with 'Artists Help Spain', an exhibition organised by the popular front coalition Artists’ International Association, which was supported by Virginia Woolf and fellow Bloomsbury group figures including Vanessa Bell and Duncan Grant. See Lynda Morris and Robert Radford, The Artists International Association 1933-1953 (Oxford: Museum of Modern Art, 1983), 30-4.

${ }^{8}$ The quotation is from the first issue of the Daily Worker, 1 January 1930 . Woolf, 'Why Art To-Day Follows Politics’, Daily Worker, 14 December 1936.

${ }^{9}$ Significant recent scholarship on the novel includes Marina MacKay, 'Putting the House in Order: Virginia Woolf and Blitz Modernism', Modern Language Quarterly 66.2 (June 2005), 227-52 and Jed Esty, A Shrinking Island: Modernism and National Culture in England (Princeton and Oxford: Princeton University Press, 2004). 10 The Communist International had formally adopted the Popular Front strategy at its seventh Congress in September 1935; Dimitrov's statement was published as The Working Class Against Fascism (London: Martin Lawrence, 1935). Quoted material from The March of English History (London: Communist Party of Great Britain, 1936), 12. This is the programme for a communist marching pageant held in Hyde Park, London in September 1936.

11 As in Karen Schneider, Loving Arms: British Women Writing the Second World War (Lexington: University Press of Kentucky, 1997), 109-33.

12 Woolf, Diary V, 133. 
${ }^{13}$ Virginia Woolf, A Room of One's Own and Three Guineas ed. Morag Shiach

(Oxford: OUP 1992). Woolf makes the point in footnote 1 to part 3 of Three

Guineas, 397.

${ }^{14}$ Woolf, Diary V, 135.

${ }^{15}$ Woolf, Diary V, 137.

16 The text's development is charted in Mitchell A Leaska ed., Virginia Woolf, Pointz

Hall: The Earlier and Later Typescripts of Between the Acts (New York: University

Publications, 1983).

17 Woolf, Diary V, 139.

18 Virginia Woolf, Between the Acts (1941: London: Penguin 1992), 7, 8, 9, 47. All

references to this text are hereafter cited parenthetically by page number and abbreviated $B$.

19 Virginia Woolf to Ethel Smyth, 1 March 1941 reprinted in Nigel Nicolson and Joanne Trautmann eds, The Letters of Virginia Woolf, Volume Six 1936-1941 (New York and London: Harcourt Brace Jovanovich, 1980), 474-75.

${ }^{20}$ Virginia Woolf, ‘The Leaning Tower’ in Virginia Woolf, Collected Essays, Volume Two ed. Andrew McNeillie (London: Hogarth, 1996), 167. Leonard Woolf recalls the pre-war period as one characterised by 'an ordered way of life [...] -a civilization of sorts’. Barbarians at the Gate (London: Victor Gollancz, 1939), 13.

The affectionately recreated Edwardian pageantry was itself already ‘made up’ in both senses of the phrase—created like fiction and assembled from available cultural materials, such as Elizabethan pageantry, to construct the nation as a family untroubled by class division and united against foreign adversaries. For pageantry as invented tradition, see Esty, Shrinking Island, 54-62 and Ayako Yoshino, 'Between 
the Acts and Louis Napoleon Parker-the Creator of the Modern English Pageant', Critical Survey 15.2 (2003), 49-60.

${ }^{21}$ John Lehmann, Whispering Gallery (London: Longman), 225.

${ }^{22}$ E. M. Forster, England's Pleasant Land (London: Hogarth Press, 1940). The pageant was performed on 9, 14 and 16 July 1938. His ‘Abinger Pageant’ was performed on 14 and 18 July 1934. Both pageants are reprinted in E. M. Forster, Abinger Harvest and England's Pleasant Land ed., Elizabeth Heine (London: André Deutsch, 1996). I am grateful to Jed Esty’s work for bringing these pageants to my attention. See his Shrinking Island, 76-85.

23 'England's Pleasant Land' in Heine ed., 353-401.

${ }^{24}$ T. S. Eliot, The Rock (London: Faber \& Faber, 1934).

${ }^{25}$ The first quotation is from Ted Bramley’s untitled report for International Press Correspondence, 26 September 1936, 12; the second is from The March of English History (London: Communist Party of Great Britain, 1936). For popular front theatrical pageantry see Mick Wallis, 'Pageantry and the Popular Front: Ideological Production in the 1930s', New Theatre Quarterly 38 (May 1994), 132-156. See also the Popular Front pageant as historiography in A.L. Morton, A People’s History of England (London: Victor Gollancz, 1938) and Jack Lindsay, England, My England: A Pageant of the English People (London: Fore Publications, nd [1939]), and the pageant as anthology in Jack Lindsay and Edgell Rickwood, A Handbook of Freedom: A Record of English Democracy Through Twelve Centuries (London: Lawrence and Wishart, 1939).

${ }^{26}$ Brenda R. Silver ed., ““Anon” and “The Reader”: Virginia Woolf’s Last Essays’, Twentieth Century Literature 25 (1979), 356-441. All references to this text are hereafter cited parenthetically by page number and abbreviated $A R$. 
${ }^{27}$ Woolf, Diary V, 304.

28 Edmund Wilson, Axel’s Castle, (1931; London: Fontana, 1984), 104.

${ }^{29}$ Christopher Caudwell, Illusion and Reality (1937; London: Lawrence and Wishart, 1973); Edgell Rickwood, 'Culture, Progress and the English Tradition’ in Cecil Day Lewis ed., The Mind in Chains: Socialism and the Cultural Revolution (1937:

London: Muller, 1938), 235-56.

30 'It was the printing press that finally was to kill Anon', 'The first blow has been aimed at Anon when the authors [sic] name is attached to the book', 'Anon is losing his ambiguity’ (AR, 384, 385, 385).

31 'What images and saws and proverbial sayings must still be current with them that have never reached the surface of print, and very likely they still keep the power we have lost of making new ones.' Virginia Woolf, Introductory Letter to Margaret Llewelyn Davies, in Lleweln Davies ed., Life As We Have Known it by Co-operative Working Women (1931; London: Virago, 1990), xxix-xxx.

32 Virginia Woolf to Ethel Smyth, 1 March 1941 reprinted in Nigel Nicolson and Joanne Trautmann eds, The Letters of Virginia Woolf, Volume Six 1936-1941 (New York and London: Harcourt Brace Jovanovich, 1980), 474; AR, 429.

${ }^{33}$ FR Leavis, 'Mass Civilisation and Minority Culture’ (1933) reprinted in John Storey ed, Cultural Theory and Popular Culture: A Reader $3^{\text {rd }}$ Edition (1994; Harlow: Pearson 2006), 14-17.

${ }^{34}$ W. H. Auden, Introduction to Auden ed., The Oxford Book of Light Verse (1938; Oxford: OUP, 1973), xv.

${ }^{35}$ Christopher Caudwell, Studies in a Dying Culture (1938; London: Bodley Head, 1951), xxiii; Christopher Caudwell, Illusion and Reality (1937; London: Lawrence and Wishart, 1973), 77. 
${ }^{36}$ Christopher Caudwell, Illusion and Reality (1937; London: Lawrence and Wishart, 1973), 281.

37 Christopher Caudwell, Studies in a Dying Culture (1938; London: Bodley Head, 1951), 54 .

${ }^{38}$ Christopher Caudwell, Illusion and Reality (1937; London: Lawrence and Wishart, 1973), 323.

${ }^{39}$ Edgell Rickwood, ‘Culture, Progress and the English Tradition’ in Cecil Day Lewis ed., The Mind in Chains: Socialism and the Cultural Revolution (1937: London: Muller, 1938), 251.

40 Raymond Williams, ‘The Bloomsbury Fraction' (1980), reprinted in Problems in Materialism and Culture (London: Verso, 1997), 168.

41 See, for example, Woolf’s famous essay ‘Modern Fiction’ (1919), reprinted in Collected Essays II (London: Hogarth, 1966), 103-111, which marked her distance from writers such as H.G. Wells, Arnold Bennett and John Galsworthy who ‘spend immense skill and immense industry making the trivial and transitory appear the true and enduring' (105). 'We found ourselves living in the springtime of a conscious revolt against the social, political, religious, moral, intellectual and artistic institutions, beliefs and standards of our fathers and grandfathers', recalled Leonard Woolf of high Bloomsbury in the first volume of his autobiography. Leonard Woolf, Sowing (London: Hogarth Press, 1964), 164.

42 Woolf, Diary V, 298.

43 'I shall thread a necklace through English life \& lit.' Diary V, 327.

44 Julian Bell, 'Nonsense’ (1938) reprinted in Robin Skelton ed., Poetry of the Thirties (Harmondsworth: Penguin, 1964), 62-3. Woolf cautioned against forcing literature’s nuance and suggestiveness into ‘up-do-date dress’ [sic] ‘to propagate 
political opinions'. 'Literature will suffer the same mutilation that the mule has suffered', she wrote, 'and there will be no more horses'. Virginia Woolf, A Room of One’s Own and Three Guineas ed. Morag Shiach (Oxford: OUP 1992). Woolf makes the point in a footnote to Three Guineas (1938), 395. Fredric Jameson, The Political Unconscious: Narrative as a Socially Symbolic Act (1981: London: Routledge, 1983), 19.

45 David McWhirter, 'The novel, the play and the book: Between the Acts and the tragicomedy of history', ELH 60 (1993), 809.

46 Marina MacKay, 'Putting the House in Order: Virginia Woolf and Blitz Modernism’, Modern Language Quarterly 66.2 (June 2005), 249.

${ }^{47}$ A reading of Restoration Comedy aptly foregrounded by Gary Day in Class (London: Routledge, 2001), 83-4.

${ }^{48}$ Woolf, Diary V, 102.

49 E.M. Forster's England's Pleasant Lands closes with a 'Pageant of Horrors' of 'Motor cars, motor bikes, motor buses, paper and empty tins' and shrieking daytrippers waving to 'families in bungalows who shriek and wave back.' E. M. Forster, Abinger Harvest and England's Pleasant Land ed., Elizabeth Heine (London: André Deutsch, 1996), 400. George Orwell’s Coming up for Air (1939; London: Penguin, 1984) narrates George Bowling’s return to Lower Binfield, the location of his fondly recalled Edwardian childhood, to find the village absorbed into suburbia. The Woolfs were themselves vigilant around the issue of unwanted development on the Sussex Downs, where population increased sharply in the 1920s, and where seventy five types of new bungalows were built. John Lowerson, 'Battles for the Countryside in F. Gloversmith ed., Class, Culture and Social Change (Brighton: Harvester, 1980), 258. Virginia Woolf objected to the absence of 'all aesthetic quality' in bungalow 
developments (Light, Mrs Woolf, 249); Leonard Woolf sat on the local Rural District

Council from where he opposed plans for development. Victoria Glendinning, Leonard Woolf: A Life (London: Simon \& Schuster 2006), 306.

50 Jack Lindsay, 'Not English? A Reminder for May Day’, Left Review (May 1936),

353-57. Extracts from a series of Communist Party pageants are reprinted in Mick Wallis, 'Pageantry and the Popular Front: Ideological Production in the 1930s', New Theatre Quarterly 38 (May 1994), 132-156. Others examples include Suffolk Labour Day’s People’s Pageant Procession, 17 June 1933, which includes sections on the Tolpuddle martyrs, the Rochdale pioneers and Chartism. The programme can be found at Manchester's Labour History Archive and Study Centre, LHASC Box 372.4. 51 Woolf to Ethel Smyth, 14 November 1940, reprinted in Nigel Nicolson and Joanne Trautmann eds, The Letters of Virginia Woolf, Volume Six 1936-1941 (New York and London: Harcourt Brace Jovanovich, 1980), 445.

52 The Leaning Tower' in Virginia Woolf, Collected Essays, Volume Two ed. Andrew McNeillie (London: Hogarth, 1996), 180, 181.

${ }^{53}$ Diary V, 289. Perhaps adjusting her tone for the context, Woolf adopted more modern terminology in the Daily Worker, writing 'Art is the first luxury to be discarded in times of stress; the artist is the first of the workers to suffer.' Woolf, ‘Why Art To-Day Follows Politics’, Daily Worker, 14 December 1936.

54 Virginia Woolf, Pointz Hall, The Earlier and Later Typescripts of Between the Acts ed., Mitchell A. Leaska (New York: University Publications, 1983), 162. Leftist artists from the Artists International Association, for example, were involved in painting politically instructive murals for the Peace Pavilion at the 1937 Paris Peace Exhibition. See Lynda Morris and Robert Radford, The Artists International Association 1933-1953 (Oxford: Museum of Modern Art, 1983), 37. 
${ }^{55}$ Woolf, ‘Modern Fiction’ (1919), reprinted in Collected Essays II (London:

Hogarth, 1966), 105.

56 This mode was appropriated by E. M. Forster's pro-feudal pageantry in the form of a microphoned voice urging his audience to ‘work together' and resist development's ‘senseless squalor.’ E. M. Forster, ‘England's Pleasant Land’ in Abinger Harvest and England's Pleasant Land ed., Elizabeth Heine (London: André Deutsch, 1996), 4001.

57 Clifford Odets’ Waiting for Lefty (1935) deals with the New York City taxis strike of 1934. It concludes with the audience raising their voices with the actors in the call for 'strike', is the most famous example of the genre, and was performed widely in Britain from 1935 onwards. The play crystallised an agitprop genre already flourishing in Britain in plays scripted by members of the Workers' Theatre Movement such as 'Meerut' (1933), 'War' (1932) and 'The First of May’ (1932). All are reprinted in Raphael Samuel, Ewan MacColl and Stuart Cosgrove eds, Theatres of the Left 1880-1935: Workers’ Theatre Movements In Britain and America (London: Routledge, 1985). Unity Theatre’s Busmen (1938), which dramatised the political lessons from the Coronation Bus Workers’ strike of 1937, came to a similar conclusion. Colin Chambers, The Story of Unity Theatre (London: Lawrence\& Wishart,1989), 140-46.

${ }^{58}$ See for example Jack Lindsay, ‘A Plea for Mass Declamation’, Left Review (October 1937), 511-20. For Lindsay mass declamation symbolically enacted the overcoming of the alienation of artist from audience and culture from labour that characterised bourgeois culture. 'Mass declamation', he wrote, 'becomes the form of contact from which endless new developments can stem; the Thespis' cart, the miracle-play platform in the market-place, which is the prerequisite of a new depth of 
drama; the first statement of the new convictions of the relationship without which the future’s lyric can never be born’ (517). Lindsay’s mass declamation 'Not English’ was published in Left Review (May 1936), his ‘On Guard for Spain’ in Left Review (March 1937). Both were widely performed at rallies and public meetings during the popular front period.

59 For the history of these groups, see Richard Stourac and Kathleen McCreery, Theatre as a Weapon: Workers’ Theatre in the Soviet Union, Germany and Britain, 1817-1934 (London: Routledge \& Kegan Paul, 1986).

${ }^{60}$ Woolf, Diary V, 135.

${ }^{61}$ Raymond Williams, 'The Bloomsbury Fraction’ (1980), reprinted in Problems in Materialism and Culture (London: Verso, 1997), 168, 165.

62 Woolf was working on her biography of Roger Fry during this period. She quotes at length from his famous catalogue introduction to the second Post-Impressionist Exhibition (1912). 'Now these artists do not seek to give, what can, after all, be but a pale reflex of actual appearance, but to arouse the conviction of a new and definite reality. They do not see to imitate form, they create form, not to imitate life, but to find an equivalent for life.’ Woolf, Roger Fry (1940: London: Vintage, 2003), 17677.

${ }^{63}$ Virginia Woolf, Pointz Hall, The Earlier and Later Typescripts of Between the Acts ed., Mitchell A. Leaska (New York: University Publications, 1983), 163, 409.

Woolf's own feelings about the 'middlebrow' culture epitomised by the BBC (for Woolf, the 'Betwixt and Between Company') are caught in her heavily ironic piece, 'Middlebrow'. Woolf, Collected Essays II (London: Hogarth, 1966), 202.

64 The Leaning Tower' in Virginia Woolf, Collected Essays, Volume Two ed. Andrew McNeillie (London: Hogarth, 1996), 181. 
${ }^{65}$ Lucy Swithin's reading material, based closely on G M Trevelyan's History of England (1926), is used throughout Woolf's text, and particularly its final section, to telescope evolutionary time and elide distinctions between the primal instincts of the embryonic species and humanity in 1939.

66 An analysis persuasively developed in Marina MacKay, 'Putting the House in Order: Virginia Woolf and Blitz Modernism’, Modern Language Quarterly 66.2 (June 2005), 227-52. 'Like many of her contemporaries, writes MacKay, 'Woolf had realised that even winning the war would mean loss when the claims of social justice she supported clashed with her own class-bound tastes’ (252).

${ }^{67}$ Susan Dick ed., The Complete Shorter Fiction of Virginia Woolf (San Diego, New York and London: Harcourt, 1985). 